\title{
排水機能を有するスパイラル羽根付き鋼管 を用いたのり面補強に関する原位置試験
}

\author{
浜崎 智洋 1 - 笠間 清伸 2 ・田山 聡 3 - 前田 良刀 4 ・松方 健治 5 ・秋吉 亮平 6 \\ 1正会員 西日本高速道路株式会社 九州支社（７812-0013 福岡市博多区博多駅東3-13-15） \\ E-mail: t.hamasaki.aa@w-nexco.co.jp \\ 2正会員 九州大学准教授 大学院工学研究院社会基盤部門（干819-0395 福岡市西区元岡744） \\ E-mail: kasama@civil.kyushu-u.ac.jp \\ 3正会員 西日本高速道路株式会社＼cjkstart本社（干530-0003 大阪市北区堂島1-6-20） \\ E-mail: s.tayama.aa@w-nexco.co.jp \\ 4正会員 NEXCO西日本コンサルタンツ株式会社（テ733-0037 広島市西区西観音町17-17） \\ E-mail: y.maeda.ac@w-nexco-consul.co.jp \\ 5正会員 NEXCO西日本コンサルタンツ株式会社（テ733-0037 広島市西区西観音町17-17） \\ E-mail: k.matsukata@w-nexco-consul.co.jp \\ 6正会員 日本地研株式会社（７812-0894 福岡市博多区諸岡5-25-25） \\ E-mail: r-akiyoshi@chiken.co.jp
}

\begin{abstract}
近年, 異常降雨や大規模地震に起因寸る高速道路の被災事象が顕在化しつつあるなかで, 降雨や地震な ぞによる複合災害に効果的に対処する予防保全対策の確立が喫緊の課題となっている．そこで，この課題 を解決するために，排水ボーリングの材料として鋼管を用い，その周面にスリット形状の水抜き孔とスパ イラル形状の “羽根”を設けることにより, 排水効果と地盤補強効果を同時に期待したのり面補強工法の 開発・実用化に向けた原位置試験をおこなった。その結果，設計に必要な鋼管と地盤との付着性能を明ら かにするとともに，のり面安定の重要な要素である降雨時における盛土内水位の上昇抑制ならびに降雨後 の地盤に生じるサクションの回復に着目して，鋼管の排水性能を定量的に検証することができた.
\end{abstract}

Key Words : ground reinforcement, drainage pipe, slope disaster prevention

\section{1. はじめに}

高速道路盛土（以下，「盛土」という）は，本来，適 切な排水処理や締固め管理の徹底により密実で安定した ものが構築されており, それらの状態が長期的に保持さ れている場合，良好な耐震性能を有していることが示さ れてきた ${ }^{1)}$. しかしながら，近年，大規模地震や異常降 雨に起因して盛土の被災が発生し，高速道路の定時性が 確保できないなど，社会経済活動に深刻な影響を与えて いる事象が顕在化しつつある.

例えば，2004 年 10 月に発生した新潟県中越地震でみ られるように，地震前の集中的な降雨により盛土内水位

（以下，「地下水位」という）が上昇し，地震動により 飽和した盛土材料のせん断強度が低下した結果，大規模 な沈下・変形に至った事例が報告されている ${ }^{2)}$. また, 2009年 8 月に発生した駿河湾を震源とする地震でみられ
るように，長期の地下水の作用により盛土材料の強度や 透水性が低下した結果，地下水位の上昇等が生じ地震が 誘因となってのり面崩落に至った事例も報告されてい る ${ }^{3)}$.さらに，2011年 3 月に発生した東北地方太平洋沖 地震では，盛土材料の一部に液状化しやすい材料が使用 され，そこに水が供給され大きな地震動が加わった結果， 崩落に至った事例が報告されている ${ }^{4}$. このように，降 雨や基礎地盤からの浸透水が素因となり，盛土のせん断 強度が低下し，地震が誘因となって被害を拡大させてい る実態が見受けられるようになってきている.

一方，高速道路延長の約 4 割が供用開始から 30 年を 超え，老朽化や劣化が顕著となりつつあるなかで，高速 道路の健全性を永続的に確保し, 高速道路ネットワーク の機能を将来にわたり維持していくために，「高速道路 資産の長期保全及び更新のあり方に関する技術検討委員 会」の提言を受け 5)，“高速道路リニューアルプロジェ 
クト”が計画されている 6)その中で，盛土材料がスレ 一キング性の高い材料，粘性系や砂質系の材料で地下水 位が高いなどの高含水比状態の盛土を対象に，排水対策 や補強対策といった大規模な修繥を予定している7゙.

降雨によるのり面崩壊の主な要因は，断続的な雨水の 浸透に起因した地下水位と飽和度の上昇による盛土（地 盤）の強度低下である ${ }^{8)}$.つまり，繰り返しの降雨によ る盛土の飽和化と地下水位の上昇に伴い，のり面を形成 する盛土 (地盤) のサクションの消失に伴う強度低下や， 間隙水圧の上昇に伴う浸透破壊の発生などが具体的な要 因である。また，降雨時だけでなく，降雨後に一定時間 を経て地震などを誘因としてのり面崩壊に至るケースも ある.したがって，このような大規模地震と異常降雨に よる複合災害に効果的に対処するには，それぞれを対象 にした対策だけではなく，両者を総合的に考慮した対策 が必要となってくる ${ }^{9}$.

そこで，排水対策による地下水位や間隙水圧の抑制, サクションの早期回復，補強対策による盛土（地盤）の 強度増加を同時に得ることを期待した，排水機能を有す るスパイラル羽根付き鋼管（以下，「鋼管」という）に よるのり面補強工法（以下，「SDPR（Spiral bladed Drain Pipe Reinforcement method）」という)の開発および実用化 に向けた検討をおこなってきた.

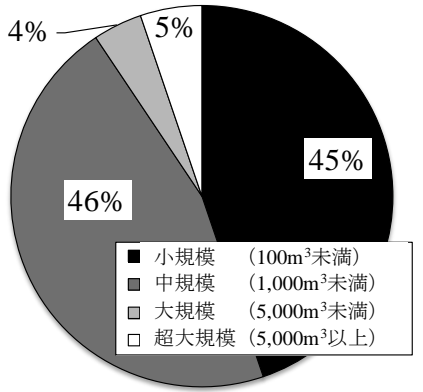

(1) 崩壊土量 (全96件)

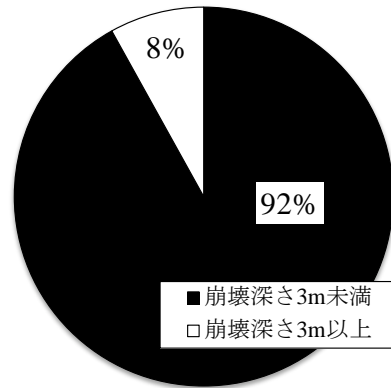

(2) 崩壊深さ (全62件)

図-1＼cjkstart降雨のり面災害規模の実態

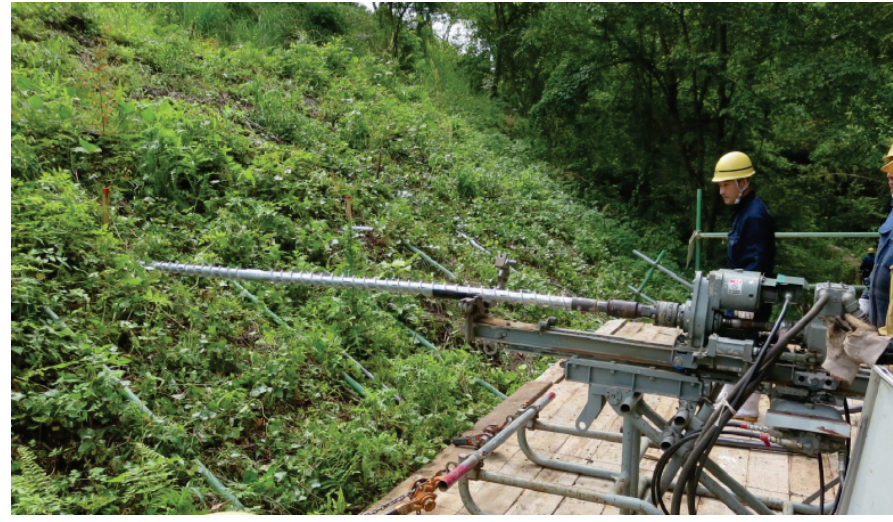

(1) 遠 景
本稿は，模型実験や解析等の既往の研究成果 100,11$)$, 12)を 踏まえ，盛土における SDPR の実施工を通じて，原位置 試験，地下水位観測やサクション計測ならびに解析等に より，のり面の安定検討に必要な鋼管と地盤との付着性 能を明らかにするとともに，のり面安定の重要な要素で ある降雨時における地下水位の上昇抑制と降雨後におけ るサクションの回復に着目し，排水性能の効果検討を実 験的に行ったものである.

\section{2. のり面災害の実態}

既往の研究 ${ }^{13)}$ によると，降雨のり面災害件数の約 $50 \%$ は盛土が飽和に近い高含水比状態になったことが要因で あり，約 40\%は排水溝等の排水施設の不備が要因である ことが報告されている．また，地形的な要因の影響も大 きく，1件あたりの平均崩壊土量が約 $400 \mathrm{~m}^{3}$ 程度なのに 対し，傾斜地盤上の盛土では $5,000 \mathrm{~m}^{3}$ 以上の大規模崩壊 の発生も報告されている。

図-1 は，平成 5～24 年度に発生した九州・沖縄の高速 道路における降雨による盛土のり面災害規模の実態をと りまとめたものである。そのうち，降雨のり面災害の規

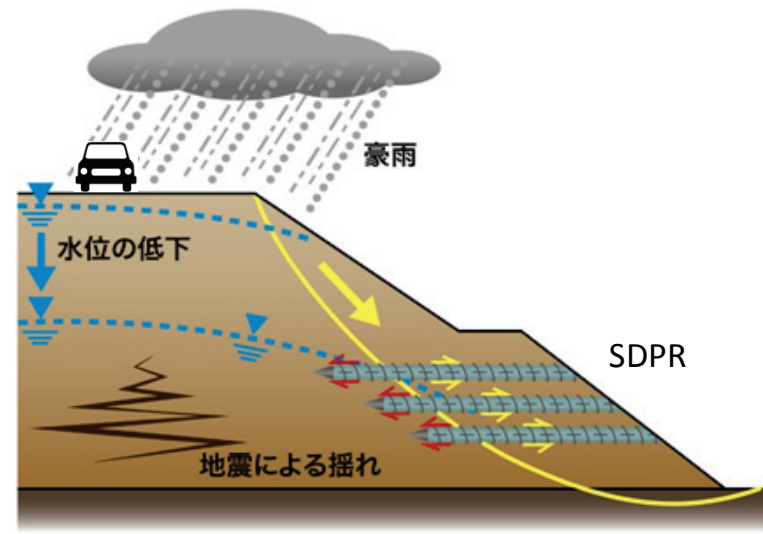

図-2ＳDPRの概要

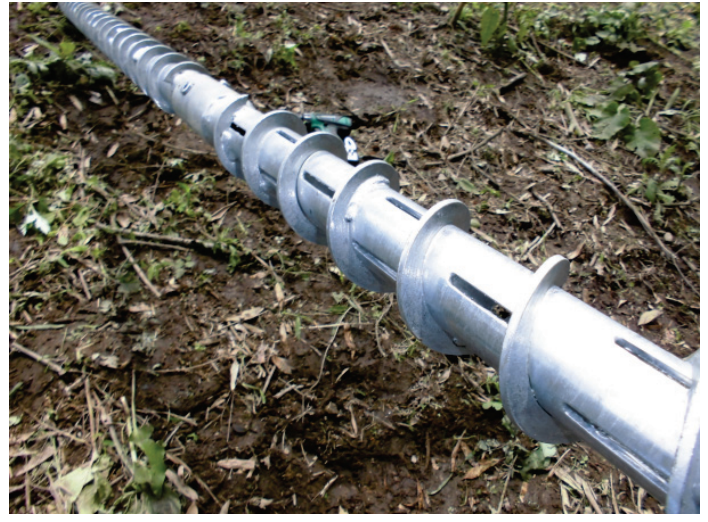

(2) 近景

写真-1 SDPRの施工状況 


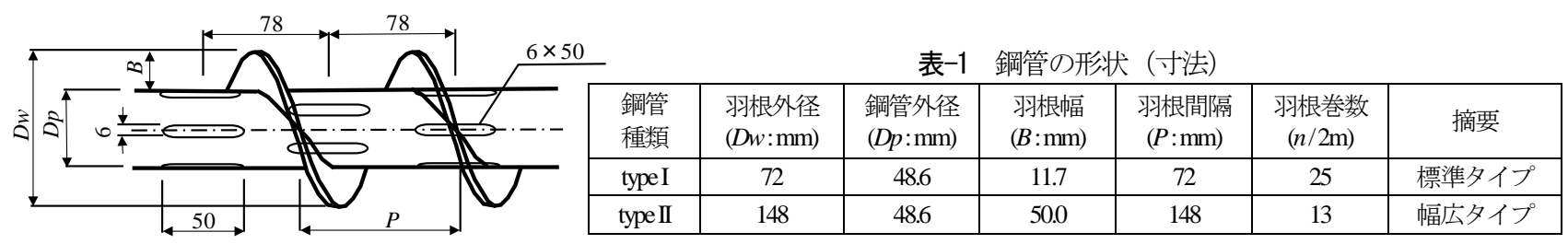

図-3 鋼管の概要図（単位 : mm)

模は，崩壊土量が $1,000 \mathrm{~m}^{3}$ 未満および崩壊深さが $3 \mathrm{~m}$ 未 満となる中規模崩壊が，それぞれ全体の約 90\%程度を占 めていることがあきらかとなった。つまり，のり面災害 を未然に防ぐにあたっては，あらかじめ崩壊深さ $3 \mathrm{~m}$ 程 度の中規模崩壊を対象とした対策を実施することが，高 速道路などの線状構造物における大部分の盛土の安定性 向上に寄与することとなる.

SDPR は，主としてこれらの中規模崩壊を対象とした のり面補強工法である。

\section{SDPR の概要}

\section{(1) SDPR の特長}

SDPR は，鋼管の周面に水抜き孔を設け，盛土内への 表面水や地下水等の浸入による地下水位や間隙水圧の上 昇を抑制するとともに，スパイラル形状の羽根を介して 鋼管と地盤との全面接着による一体化を期待した，排水 機能を兼ね備えたのり面補強工法である. SDPR の概要 を図-2に，施工状況を写真-1に示す.

SDPR に用いられる鋼管は，既に構造物基礎等の支持 杭として使用されている回転杭 ${ }^{14)}$ 応用したものであり， 既往の模型実験等による研究 ${ }^{15}$, 16)により，のり面補強効 果に関する成果が得られている.

また，排水ボーリングが設置された盛土は間隙水圧や 地下水位が低減され, 盛土の安定性向上が図られること が解析的に評価されている ${ }^{17,18) . ~}$

\section{(2) 鋼管の形状および仕様}

図-3 に鋼管の概要図，および表-1 にその形状（寸法） を示す. 鋼管は，JIS G 344 に規定される STK400（一般 構造用炭素鋼鋼管，外径 $=48.6 \mathrm{~mm}$ ，板厚 $=3.5 \mathrm{~mm} ）$ を使 用し，羽根は，JS G 3101 に規定される SS400（一般構造 用圧延鋼材，板厚 $=4.5 〜 2.2 \mathrm{~mm} ）$ を使用した.

鋼管周面には，地盤と鋼管との付着を確保するため, スパイラル形状の羽根を全長にわたり装着した。鋼管種 類 “type I” は羽根外径 $(D w)$ / 鋼管外径 $(D p)=1.5$ の標準 タイプ，鋼管種類 “type II” は羽根外径 $(D w)$ / 鋼管外径 $(D p)=3.0$ の幅広タイプである.

また，補強対策に用いた鋼管には，水抜き孔として

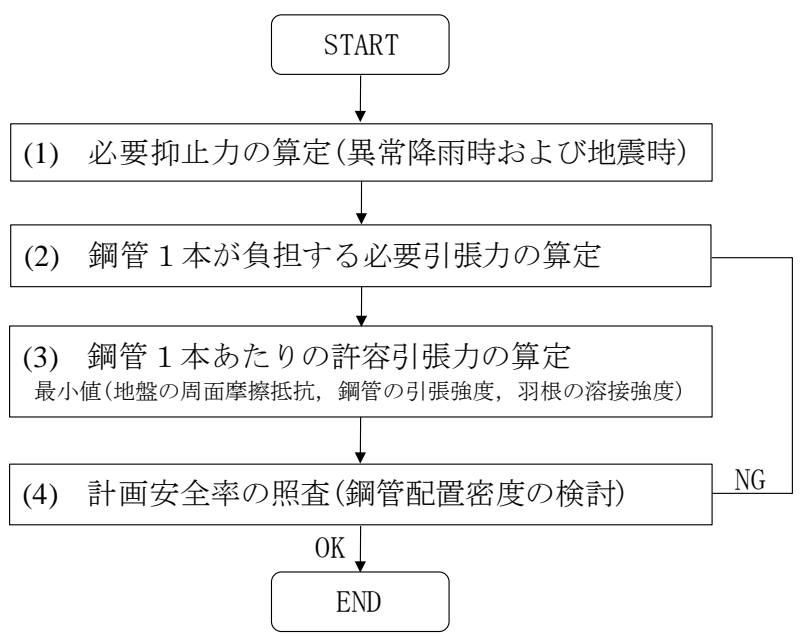

図-4 設計フロー(要旨)

6×50mm の長孔（スリット形）を開口率 10\%となるよう に鋼管周面の全長にわたり配置するとともに，JIS H 8641 に規定される 2 種 $45 （ H D$ Z 45）の溶融亜鈶めつき 処理を防錆として施した。

\section{(3) 設計フロー}

SDPR を適用したのり面の安定検討にあたっては，切 土補強土工法設計・施工要領 ${ }^{19)}$ を準用し，図-4に示す手 順において実施することとした．具体的には，異常降雨 時および地震時においてそれぞれの必要抑止力を算定し, 鋼管が負担する引張力をもとに所定の安全率を満足する よう鋼管の配置長さおよび配置密度を計算する.ここで, 鋼管が負担する引張力は，鋼管と地盤との周面摩擦抵抗， 鋼管の引張強度および习习习根と鋼管の溶接強度等の最小值 により決定される. したがって, 必要な引張力の算定に あたっては，鋼管と地盤との付着性能に係る周面摩擦抵 抗を把握することが肝要となる.

\section{(4) 施 工}

鋼管の施工にあたっては，鉄筋挿入工やロックボルト 工などに用いられるエアモータ・チェーン方式のボーリ ングマシン（最大トルク $1,230 \mathrm{~N} \cdot \mathrm{m}$ ) をベースマシンと して用いた。これに鋼管を回転させるための治具を装着 し，必要に応じて強制振動を与えながら据じ込み方式に より鋼管の圧入を行うこととした. その結果，これまで に $L=17 \mathrm{~m}$ の施工実績を得ることができた.

なお，鋼管は，これらの施工に必要なねじり強度を有 
することが必要となる。

\section{4. 地盤との付着性能に関する検討}

\section{(1) 引抜き抵抗試験}

\section{a) 試験の概要}

鋼管の施工方法や鋼管の形状が地盤との付着性能に及 ぼす影響ならびに周面摩擦抵抗を把握することを目的に, 引抜き抵抗試験を実施した。引抜き抵抗試験は，のり面 表層部の含水比が高く, 脆弱化していると考えられる 5 箇所の盛土において実施した。

盛土材料の物性等諸元は表-2 に示寸とおりであり, 代表 $N$ 值とは，試験箇所の調査により得られた $N$ 值の 平均值である.

なお，鋼管の試験体長さは 5～6m を標準とし，砂等 の介在により鋼管の圧入が困難となった場合は，圧入で きた長さに応じて引抜き抵抗值を評価した.

\section{b) 試験方法}

引抜き抵抗試験は，ロックボルト引抜き試験方法 （JGS 3731-2012）に準じて実施した。試験にあたっては, 鋼管に特殊加工した治具を取付けテンションバーと接続 させ，それを介して油圧ジャッキにて載荷を行った（写 真-2および図-5参照) .

\section{（2）引抜き抵抗試験結果}

図-6に引抜き抵抗試験により得られた代表的な荷重 一変位曲線を示寸 (図中の凡例に示寸番号は，表-3 中 の番号等に対応する）。最大荷重時の引抜き変位量は試 験体長さの $0.3 \sim 1 \%$ 程度であった.

表-3 に試験体長さおよび鋼管種類の諸元に基づく極 限周面摩擦抵抗 $(\tau)$ の算出結果を示す．引抜き抵抗荷重 は，荷重一変位曲線における最大荷重とした，その結果， 代表 $N$ 值 $=3$ の場合（試験箇所 D）において $\tau=45 \mathrm{kN} / \mathrm{m}^{2}$, 代表 $N$ 值 $=8$ の場合（試験箇所 C）において $\tau=97 \mathrm{kN} / \mathrm{m}^{2}$ が得られた。 また，試験箇所 Aおよび Bにおいて，type II は, type I と比較して極限周面摩擦抵抗 ( $(\tau)$ が 10～30\% 程度高くなる傾向が得られた。

図-7に，代表 $N$ 值と極限周面摩擦抵抗 $(\tau)$ との関係を プロットした（図中の凡例に示寸記号は，表-3 中の試 験箇所およひ鋼管種類に対応する）。この結果，両者は かなり強い相関関係（相関係数 $r=0.92 ） に あ り$, 代表 $N$ 值を用いて極限周面摩擦抵抗 $(\tau)$ を $\tau=10 \cdot N+13$ で推定で きる結果が得られた（図-7中の実線）。

さらに，切土補強土工法に用いられる粘性土の極限周 面摩擦抵抗 $(\tau)$ の推定值（図-7 中の破線）と比較を行っ た. この場合 $\tau^{\prime}=0.8 \cdot c$ (ここに, $c$ : 粘着力）で推定さ れ, 粘着力 (c) は各種提案されている推定式のなかで $c=$
表-2 引抜き抵抗試験箇所の物性等諸元

\begin{tabular}{|c|c|c|c|c|}
\hline $\begin{array}{l}\text { 試験 } \\
\text { 箇所 }\end{array}$ & 盛土材料分類 & $F c(\%)$ & Ip & 代表 $N$ 值 $\%$ \\
\hline $\mathrm{A}$ & 火山灰質粘性土(V) & 63.2 & 10.7 & 4 \\
\hline $\mathrm{B}$ & 粘性土(Cs) & 80.5 & 17.1 & 5 \\
\hline $\mathrm{C}$ & 砂質土(S) & 20.4 & 10.5 & 8 \\
\hline $\mathrm{D}$ & 砂質土(S) & 41.2 & 57.3 & 3 \\
\hline $\mathrm{E}$ & 砂質土(S) & 40.3 & 16.5 & 5 \\
\hline
\end{tabular}

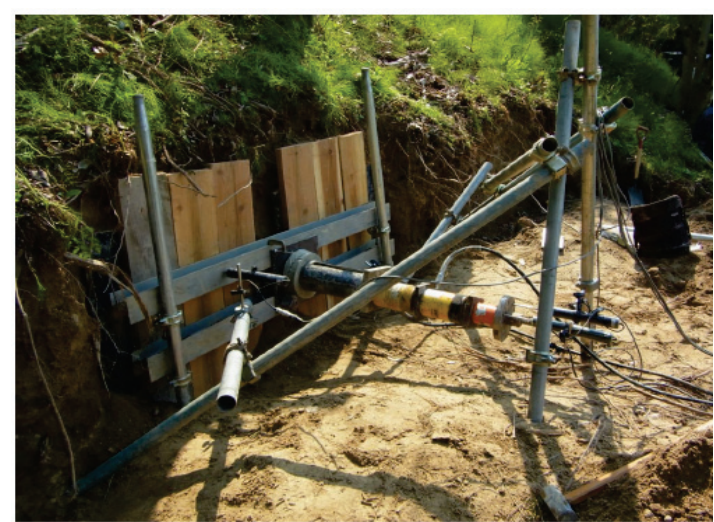

写真-2 引抜き抵抗試験状況

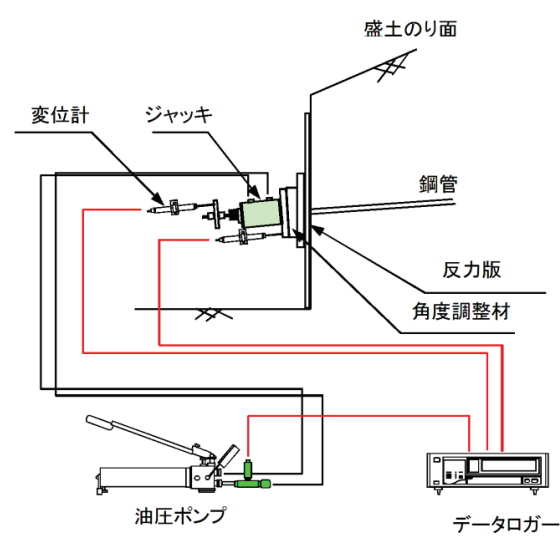

図-5引抜き抵抗試験の概要

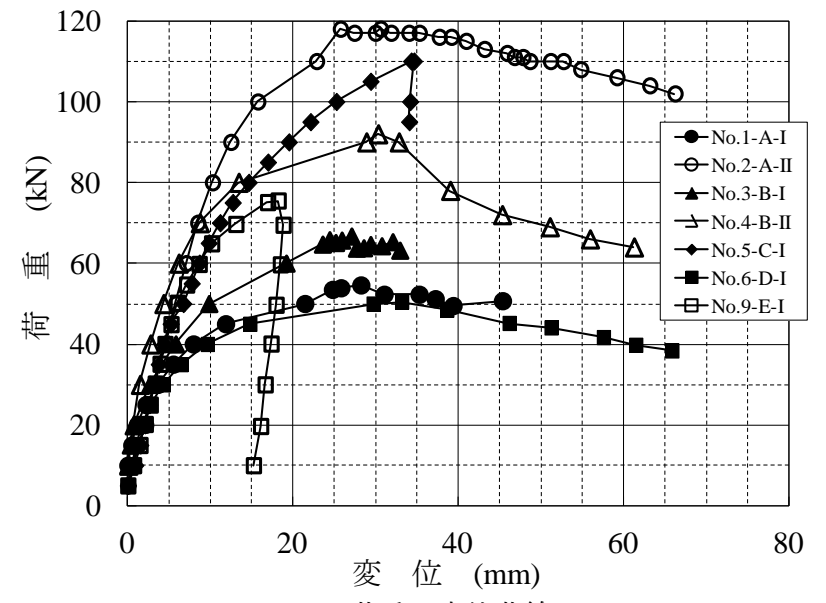

図-6 荷重一変位曲線 
10·N 20)を引用した。 その結果，SDPR で得られた極限周 面摩擦抵抗 $(\tau)$ は，切土補強土工法において想定されて いる場合と同等以上の付着性能を期待できることが示さ れた.

\section{5. 地下水の動態からみた排水性能}

\section{（1） SDPRによる補強対策事例（その 1)}

図-8 に示すような集水地形に位置する片切片盛構造 の腹付け盛土（表-2 中の試験箇所 D に該当）において, SDPR による補強対策を行った。盛土は火砕流堆積物の しらすが広域に分布する台地の低地に位置しており，礫 混じり火山灰質砂を主体とした高さ $12 \mathrm{~m}$ 程度の 2 段盛 土である．対象盛土の土質特性を表-4に示す。

のり面の安定検討にあたっては，過去の近傍における 降雨によるのり面崩壊事例を参考に，盛土内に異常降雨 等による最高水位を設定し，常時と地震時のそれぞれの 計画安全率を満足するか否かの検討を行った，次に，鋼 管を配置したことによる地下水位の低下（GL-3.5m：鋼 管配置高さに相当)を想定し，計画安全率を満足するよ う鋼管の配置密度の検討を行った. その結果，下方から 1段目のり面の上段および下段に，それぞれ $L=11 \mathrm{~m}$ お よび $L=9 \mathrm{~m}$ の鋼管を $3 \mathrm{~m}$ 間隔（のり面配置密度 : 1 本 $/ 9$ $\left.\mathrm{m}^{2}\right)$ で配置することとした.

\section{（2）地下水位観測}

SDPR による排水性能を検討するにあたり，SDPR に よる補強対策を行った箇所（以下，「SDPR 有」という） と無対策箇所（以下，「SDPR 無」という）における地 下水位の動態について検証をおこなった。

地下水位観測は，図-8 に示すのり面小段付近で No.1 観測孔（SDPR 有）と，隣接した No.2 観測孔（SDPR 無） において実施した。検討対象の観測期間は，2015 年 4 月 11 日から 2016年12月 11 日までとした.

図-9 に，観測期間における雨量と地下水位の観測結 果を示す．観測期間中の最大日雨量は 167mm であり, カナンプロットのプロッティングポジション公式 ${ }^{21)}$ によ り再現期間 2 年の年最大日雨量に相当する. また， 2015 年 4 月 11 日から 1 年間の年間降水量は $3,627 \mathrm{~mm}$ であり, 同様に再現期間 25年の年間降水量に相当する.

地下水位は No.1 観測孔で GL-5.9〜-2.4m, No.2 観測孔 で GL-6.0〜-1.5m の変動があった. No.1 観測孔では，一 時的に GL-3.5m を超過する降雨があったものの, No.2 観 測孔と比較して，地下水位は速やかに低下寸る傾向を示 した. 一方，No.2 観測孔では，50mm/日を超える降雨に より定常的に GL-3.5m を超過する傾向を示した. また， 観測期間中の No.1 観測孔と No.2 観測孔の水位差は最大
表-3 極限周面摩擦抵抗 $(\tau)$ の算出結果

\begin{tabular}{|c|c|c|c|c|c|}
\hline No. & $\begin{array}{c}\text { 試験 } \\
\text { 箇所 }\end{array}$ & $\begin{array}{c}\text { 鋼管 } \\
\text { 種類 }\end{array}$ & $\begin{array}{c}\text { 試験体 } \\
\text { 長さ } \\
(L: m)\end{array}$ & $\begin{array}{c}\text { 引抜き } \\
\text { 抵抗荷重 } \\
(P: \mathrm{kN})\end{array}$ & $\begin{array}{c}\text { 極限周面 } \\
\text { 摩摖抵抗 } \\
\left(\tau: \mathrm{kN} / \mathrm{m}^{2}\right)\end{array}$ \\
\hline 1 & $\mathrm{~A}$ & type I & 5 & 54 & 48 \\
\hline 2 & $\mathrm{~A}$ & type I & 4 & 118 & 63 \\
\hline 3 & $\mathrm{~B}$ & type I & 5 & 66 & 58 \\
\hline 4 & $\mathrm{~B}$ & type II & 3 & 92 & 66 \\
\hline 5 & $\mathrm{C}$ & type I & 5 & 110 & 97 \\
\hline 6 & $\mathrm{D}$ & type I & 5 & 51 & 45 \\
\hline 7 & $\mathrm{D}$ & type I & 5 & 51 & 45 \\
\hline 8 & $\mathrm{D}$ & type I & 5 & 50 & 44 \\
\hline 9 & $\mathrm{E}$ & type I & 6 & 75 & 55 \\
\hline 10 & $\mathrm{E}$ & type I & 6 & 73 & 54 \\
\hline 11 & $\mathrm{E}$ & type I & 6 & 81 & 60 \\
\hline 12 & $\mathrm{E}$ & type I & 6 & 90 & 66 \\
\hline
\end{tabular}

※極限周面摩擦抵抗( $(\tau)$ は, 引抜き抵抗荷重を試験体長さおよび 羽根外径周長で除した值 : $\tau=P / L /(D w \cdot \pi)$

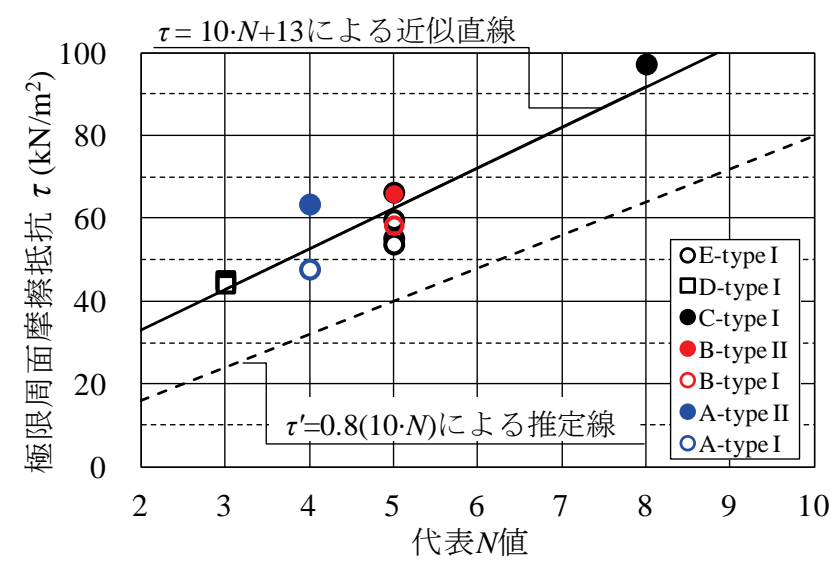

図-7 代表 $N$ 值と極限周面摩擦抵抗との関係

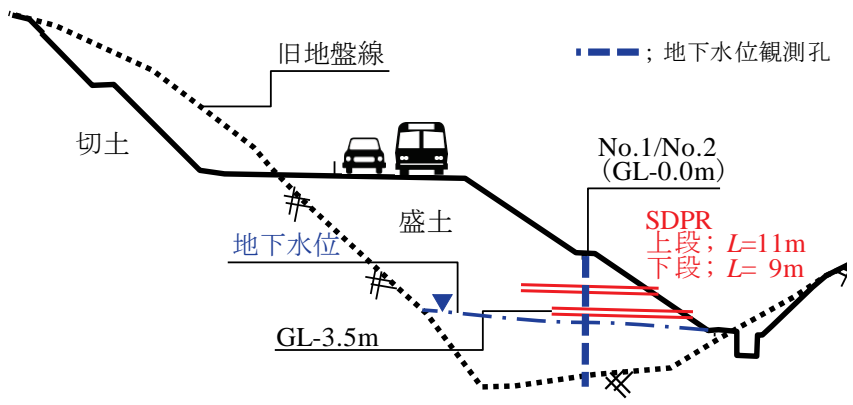

図-8ＳDPRによる補強対策の概要

表-4 盛土の物理的土質特性（その1）

\begin{tabular}{|c|c|c|c|c|}
\hline $\begin{array}{c}\text { 湿潤密度 } \\
\rho_{t} \\
\left(\mathrm{~g} / \mathrm{cm}^{3}\right)\end{array}$ & $\begin{array}{c}\text { 乾燥密度 } \\
\rho_{d} \\
\left(\mathrm{~g} / \mathrm{cm}^{3}\right)\end{array}$ & $\begin{array}{c}\text { 間隙比 } \\
(-)\end{array}$ & $\begin{array}{c}\text { 自然含水比 } \\
\omega_{n} \\
(\%)\end{array}$ & $\begin{array}{c}\text { 透水係数 } \\
k_{\mathrm{s}} \\
\times 10^{5}(\mathrm{~m} / \mathrm{s})\end{array}$ \\
\hline 1.44 & 0.81 & 2.38 & 81.0 & $5.4 \sim 8.4$ \\
\hline
\end{tabular}

で 1.1m（2016/6/27） であり，100 mm /日を超える降雨の ときは，地下水上昇は最大で $1.0 \mathrm{~m}$ (2016/5/10）抑制され た.このように，SDPR による地下水位の動態に大きな 差異があることが確認できた.

なお，2016 年 9 月 4 日の前後において，地下水位は 


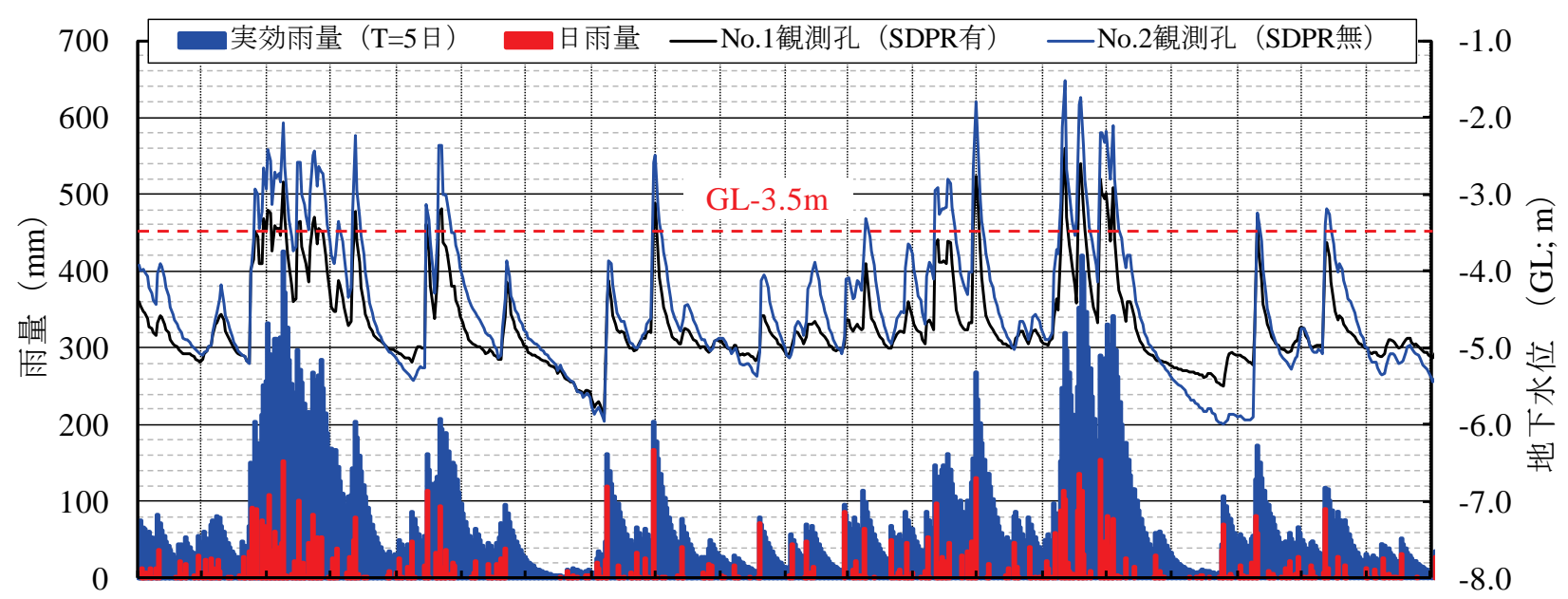

年/月/日

図-9 雨量と地下水位の観測結果（その 1)

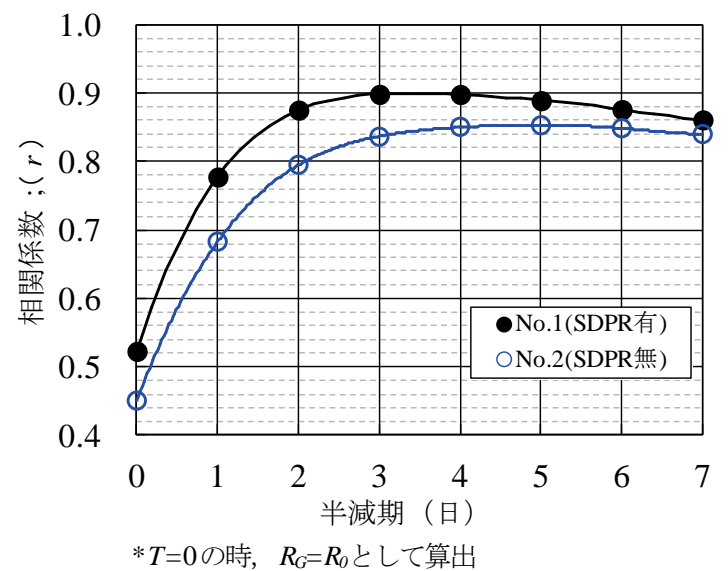

図-10 半減期ごとの相関係数（その 1$)$

No.1 観測孔より No.2 観測孔が低くなっているが，鋼管 配置高さ (GL-3.5m) 以深ののり尻 (GL-5.5m) 付近に位 置する地下水位であるため, SDPR の排水性能や盛土の 安定に影響を及ぼすような変動ではない.

\section{（3）実効雨量を用いた地下水位の動態評価}

排水性能を定量的に検討寸るために，地下水位の動態 とあわせて，先行雨量の影響を考慮した実効雨量に着目 した評価を試みた。実効雨量 ${ }^{22)}$ とは，それまでに降った 雨量が地中にどれ位残存しているかを便宜的に示した值 であり, 次式 (1) で算出される. また, 半減期は残存し ている雨量が降雨量の半分になるまでの時間の長さを表 している.

$$
R_{G}=R_{0}+\sum R_{n} \cdot(0.5)^{n / T}
$$

ここに, $R_{G}$ : 実効雨量 $(\mathrm{mm}), R_{n}: n$ 日前の雨量 $(\mathrm{mm})$,

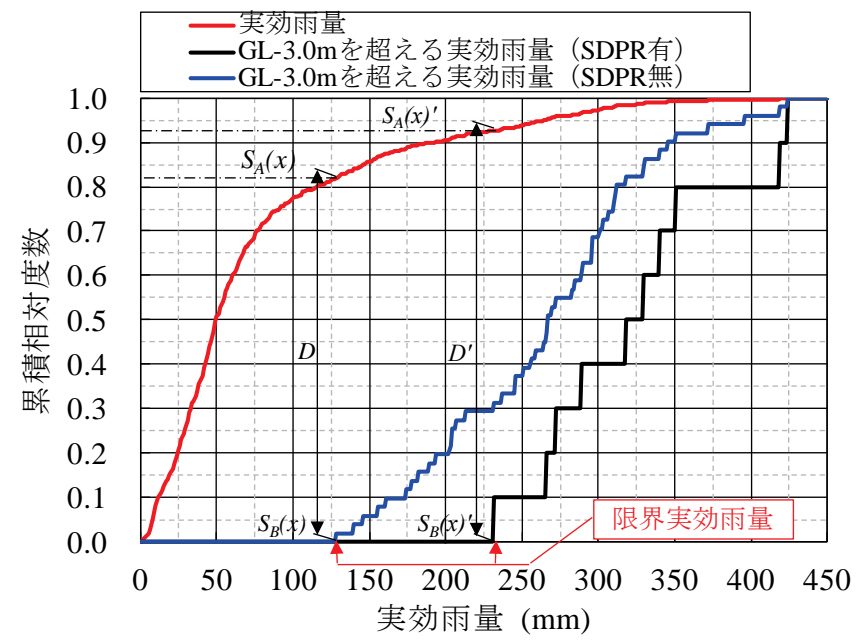

図-11 実効雨量（ $T=5$ 日）の累積相対度数

$T$ : 半減期 (日)である.

図-10は，2015年4月 11 日から 2016年 12 月 11 日まで の地下水位と, 日雨量から式 (1) により算出した実効雨 量との相関係数を, 次式 (2) を用いて計算した結果であ る. 図-10 の横軸は実効雨量を算出するのに用いた半減 期の值であり，相関係数が最大となる，つまり地下水位 の動態をうまく表現できる半減期が存在することがわか る.

$$
r=\frac{\sum_{m}\left[W_{i}-\frac{1}{m} \sum_{m} W_{i}\right] \cdot\left[R_{G i}-\frac{1}{m} \sum_{m} R_{G i}\right]}{\sqrt{\sum_{m}\left[W_{i}-\frac{1}{m} \sum_{m} W_{i}\right]^{2} \cdot \sum_{m}\left[R_{G i}-\frac{1}{m} \sum_{m} R_{G i}\right]^{2}}}
$$

ここに, $r$ : 相関係数, $W_{i}: i$ 日における地下水位, $R_{G i}$ : $i$ 日における実効雨量（半減期 $T$ 日）， $m$ : 観測日数で 
ある.

地下水位の動態と最も相関がよい実効雨量の半減期は,

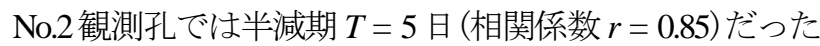
のに対し, No.1 観測孔では半減期 $T=3$ 日 (相関係数 $r=$ 0.90)となり，SDPR により半減期が短縮できることが示 された. あわせて，図-9に半減期 $T=5$ 日の場合の実効 雨量の推移を示すと, 地下水位の動態と相関が高いこと がうかがえる。

\section{（4）限界実効雨量による排水性能の評価}

ここでは，SDPR の排水性能による而降雨性の向上を 定量的に把握するために，限界実効雨量の算出を行った. ここで限界実効雨量とは，「SDPR 無の場合の降雨時に, 安全率が Fs = 1.05 となる地下水位（GL-3.0m）を超過す る実効雨量」と定義した.

算出にあたっては，以下のような手順で実施した。ま ず，半減期 $T=5$ 日の同一条件下において，SDPR有・無 ごとに観測期間中の実効雨量と地下水位 GL-3.0m を超過 した時の実効雨量について，それぞれの度数を集計した。 次に，図-11 に示すように，両者の累積相対度数の差が 最大となる実効雨量を限界実効雨量として採用した。 そ れらについては, 次式 (3) に示すコルモゴノフースミル

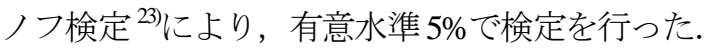

$$
D=\max \left|S_{A}(x)-S_{B}(x)\right| \geq 1.36 / \sqrt{N}
$$

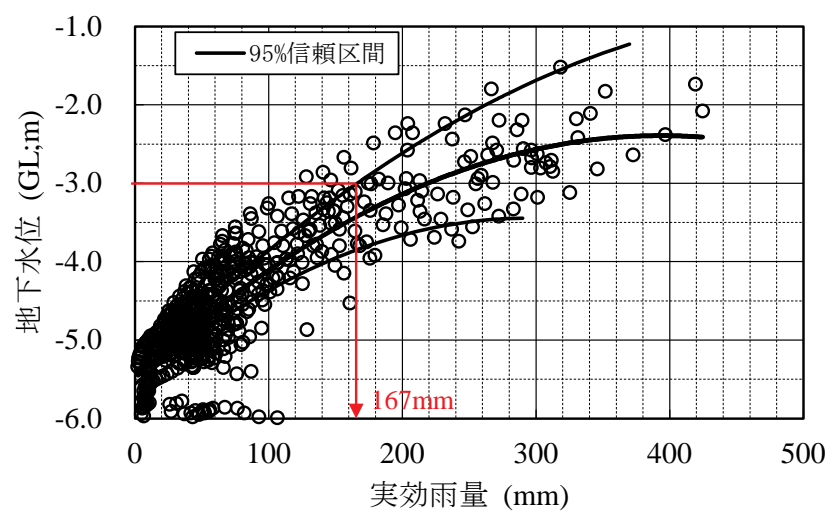

(1) SDPR 無
ここに, $D: K S$ 検定統計量, $S_{A}$ : 実効雨量の累積相対度 数, $S_{B}$ : GL-3.0m を超える実効雨量の累積相対度数, $x$ : 実効雨量 $(\mathrm{mm}), N$ : GL-3.0m を超える実効雨量の度数で ある.

その結果，限界実効雨量は SDPR 無の場合で $127 \mathrm{~mm}$ $\left(S_{A}=0.82, S_{B}=0.00, N=51\right)$, SDPR 有の場合で $232 \mathrm{~mm}\left(S_{A}{ }^{\prime}=0.93, S_{B}{ }^{\prime}=0.00, N=10\right)$ となり，SDPRに より 105mm増加する結果が得られた.

また，図-12に示すような実効雨量（ $T=5$ 日）と地下 水位との関係から回帰係数の 95\%信頼区間を計算し, それにより得られた近似曲線の上限值が地下水位 GL$3.0 \mathrm{~m}$ となる限界実効雨量を推定した。 その結果，限界 実効雨量は SDPR 無の場合で 167mm，SDPR 有の場合で $274 \mathrm{~mm}$ となり, SDPR により 107mm 増加する結果が得 られた。

このように，SDPR により，一定水位の上昇に対して 実効雨量が増加していることが確認でき，先行雨量を含 めた而降雨性の向上を期待できることが示された.

\section{6. 盛土内サクションの動態からみた排水性能}

\section{（1）SDPRによる補強対策事例（その 2）}

図-13 に示すような丘陵地の集水地形に位置する盛士 （表-2 中の試験箇所 E に該当）において，SDPR による

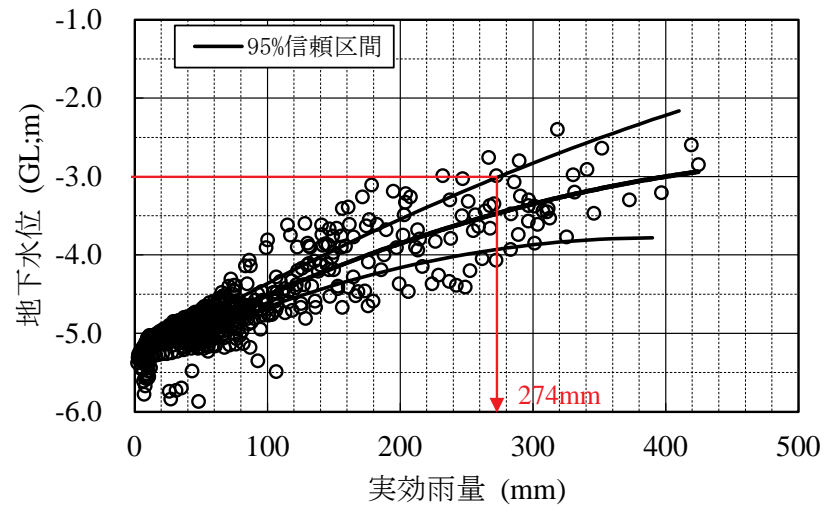

(2) SDPR 有

図-12 実効雨量（ $T=5$ 日）と地下水位との関係.

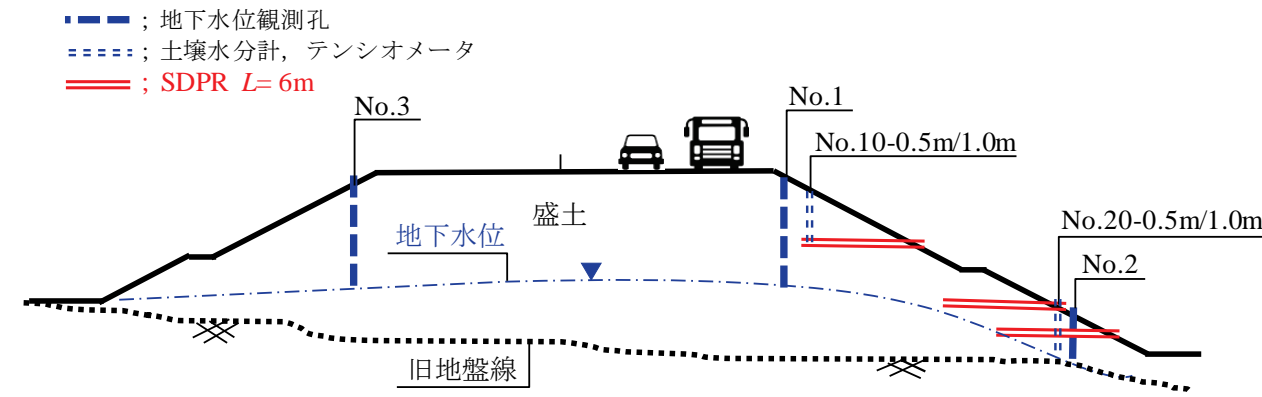

図-13ＳDPRによる補強対策と機器の設置概要 
補強対策を行った，盛土は花崗岩類を基盤とし，碩混じ り粘性土質砂を主体とした高さ $13 \mathrm{~m}$ 程度の 2 段盛土で ある. 対象盛土の土質特性を表-5に示す。

のり面の安定検討にあたっては，前述したように盛土 内に異常降雨等による最高水位を設定し, 常時と地震時 の計画安全率を満足するよう鋼管の配置密度の検討を行 った. その結果， $L=6 \mathrm{~m}$ の鋼管をのり面配置密度が 1 本 $/ 9 \mathrm{~m}^{2}$ となるよう 3 段配置した.

\section{(2) 観測概要}

サクションおよび土壌水分の動態を観測するために, 図-13 および表-6 に示すように，地下水位観測孔（No.1 〜No.3），テンシオメータ（No.10および No.20），土猿 水分計（No.10 および No.20）および雨量計を設置した。 テンシオメータおよび土壌水分計は，鋼管と鋼管の間に 位置するのり面表層から 0.5m および $1.0 \mathrm{~m}$ の深度にそれ ぞれ設置した。なお，地下水位計の No.3 観測孔は，無 対策箇所に設置した.

ここでは，これらの観測結果を用いて，降雨後の土の 有効応力の回復による地盤の強度特性の評価に大きな影 響を与えるサクションに着目して，SDPR による排水性 能の検討を試みた。

\section{（3）地下水位観測と半減期}

地下水位観測は，図-13 に示寸のり肩とのり尻付近の No.1 No.3 観測孔において実施した. 検討対象の観測期 間は，2016年 6 月 1 日から 12 月 31 日までとした。 なお， 2016 年 9 月 11 日までは SDPR による補強対策前（以下，

「SDPR 無」という），9月 17 日以降は，SDPR による 補強対策後（以下，「SDPR 有」という）の観測となっ
ている.

図-14 に観測期間中における雨量と地下水位の観測結 果を示寸．観測期間中の最大日雨量は 257mm であり， カナンプロットのプロッティングポジション公式により 再現期間 23 年の年最大日雨量に相当する.

地下水位の動態は，No.1および No.3 観測孔で GL-7.0m 以浅, No.2 観測孔で GL-4.0m 以浅で推移しているが, No.3 観測孔にみられるように，250 $\mathrm{mm} /$ 日を超える降雨 （2016/6/22）に伴い最大で 6.6m の水位上昇が確認され た．また，のり肩付近に設置した No.1 観測孔では，9月 17 日以降, No.3 観測孔と比較して降雨に伴う水位上昇 量は小さくなる傾向を示した.

図-15は，それぞれの観測孔において，地下水位の動 態と最も相関がよい実効雨量の半減期を式 (1) および式 （2）により算出した結果である．No.1観測孔では，SDPR

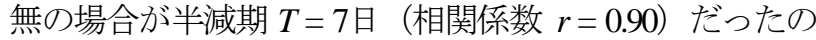
に対し,SDPR有の場合は半減期 $T=3$ 日（相関係数 $r=$

表-5 盛十の物理的土質特性（その2)

\begin{tabular}{|c|c|c|c|c|}
\hline $\begin{array}{c}\text { 湿潤密度 } \\
\rho_{t} \\
\left(\mathrm{~g} / \mathrm{cm}^{3}\right)\end{array}$ & $\begin{array}{c}\text { 乾燥密度 } \\
\rho_{d} \\
\left(\mathrm{~g} / \mathrm{cm}^{3}\right)\end{array}$ & $\begin{array}{c}\text { 間隙比 } \\
(-)\end{array}$ & $\begin{array}{c}\text { 自然含水比 } \\
\omega_{n} \\
(\%)\end{array}$ & $\begin{array}{c}\text { 透水係数 } \\
k_{\mathrm{s}} \\
\times 10^{9}(\mathrm{~m} / \mathrm{s})\end{array}$ \\
\hline 1.97 & 1.58 & 0.70 & 23.2 & $1.2 \sim 4.7$ \\
\hline
\end{tabular}

表-6 観測・計測機器の設置状況

\begin{tabular}{|c|c|c|c|}
\hline 地点 & 設置箇所 & 設置深度(m) & 観測・計測機器 \\
\hline No.1 & のり肩 & GL-8.0 & \multirow{3}{*}{ 地下水位計 } \\
\hline No.2 & のり尻 & GL-3.35 & \\
\hline No.3 & のり肩 & GL-6.8 & \\
\hline No.10 & のり肩 & \multirow{2}{*}{ GL-0.5, GL-1.0 } & 土壌水分計 \\
\hline No.20 & のり尻 & & \\
\hline- & \multicolumn{2}{|c|}{ No.1 と No.2 のほぼ中央 } & 雨量計 \\
\hline
\end{tabular}

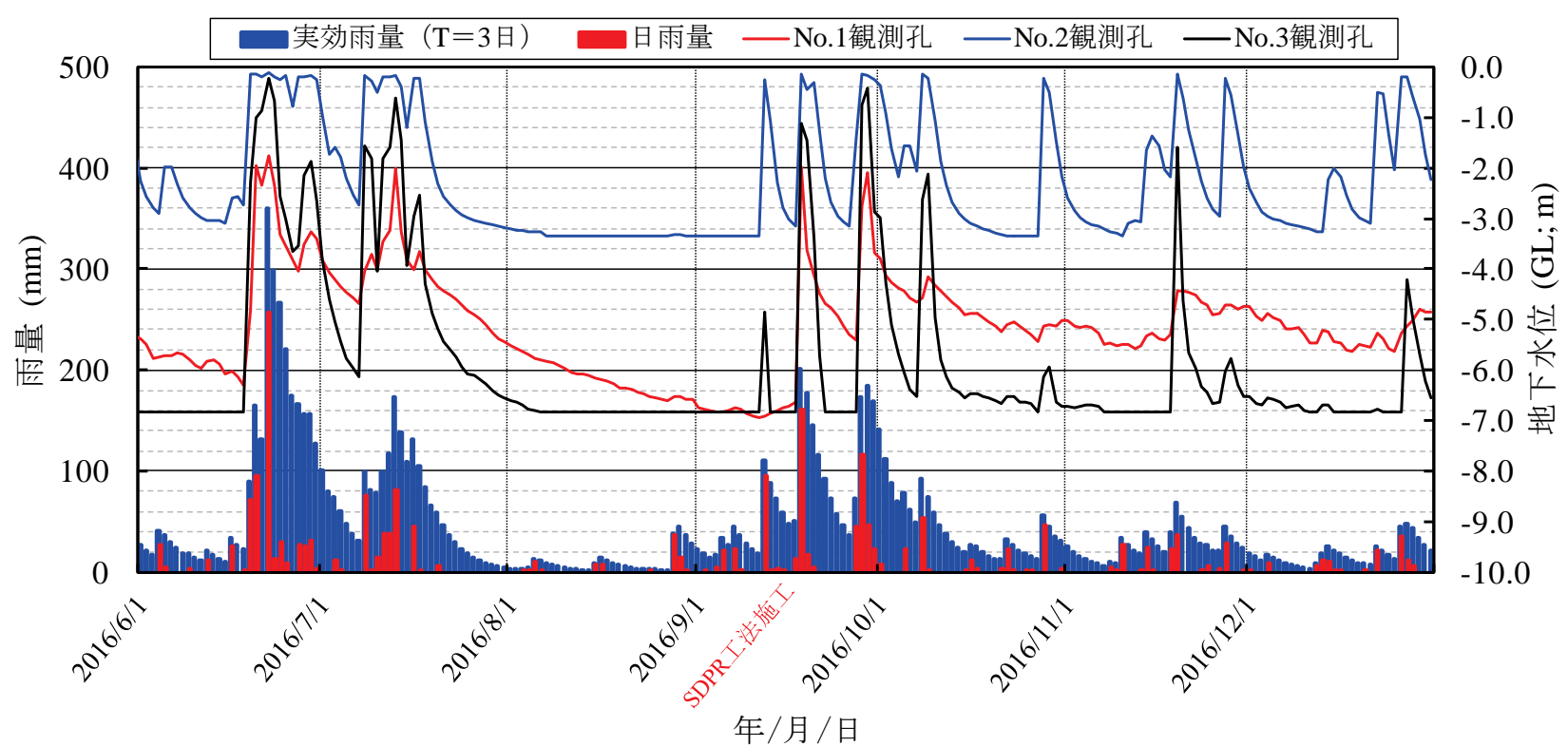

図-14 雨量と地下水位の観測結果（その 2) 
0.83）が得られ，半減期が短縮していることが示された.

また，無対策箇所に設置したNo.3観測孔から算出した

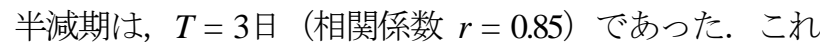
らの結果から，半減期が $T=3$ 日以上であることを想定 し，以後の実効雨量については式 (1) を用いた次式 (4) により $T=72$ 時間で検討を行った。 なお，図-14には算出 した実効雨量の推移もあわせて示しており，地下水位の 動態と相関が高いことがうかがえる.

$$
R_{G 72}=R_{0}+\sum R_{n} \cdot(0.5)^{n / 72}
$$

ここに, $R_{G 72}: 72$ 時間実効雨量 $(\mathrm{mm}), R_{n}: n$ 時間前の雨 量(mm)である.

\section{（4） 72 時間実効雨量と地下水位}

図-16 は，SDPR による排水性能の検討を具体的に実 施するために，全観測期間から累積雨量と 72 時間実効 雨量が同様な形態で推移している SDPR 無および SDPR

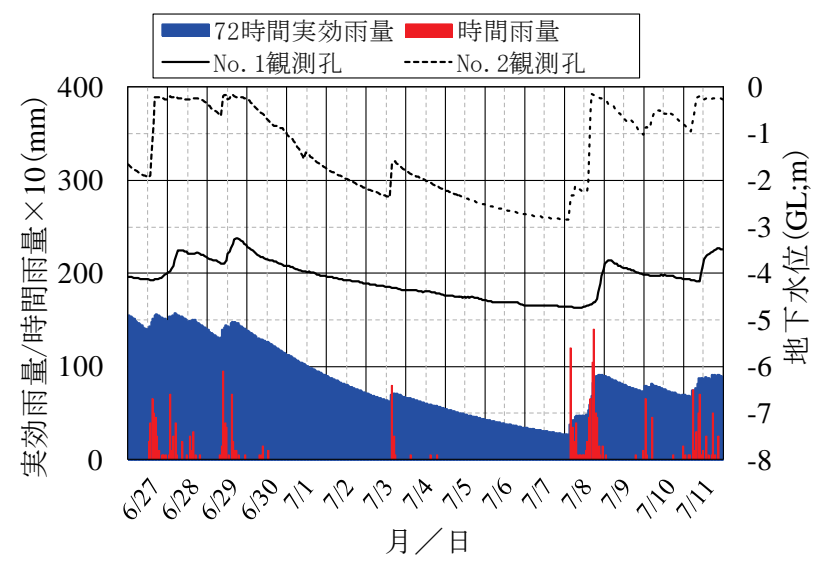

(1) SDPR 無(6/27 7/11)

図-16 雨量と地下水位の観測結果 (その3)
有の観測期間を抽出したものである。ただし，時間雨量 については, 10倍した数值で示している.

SDPR 無については，6月 27 日から 7 月 11 日までの 15 日間とし，この間の累積雨量は，229 mm であった。 一方，SDPR有については，9月19日から 10 月 3 日まで

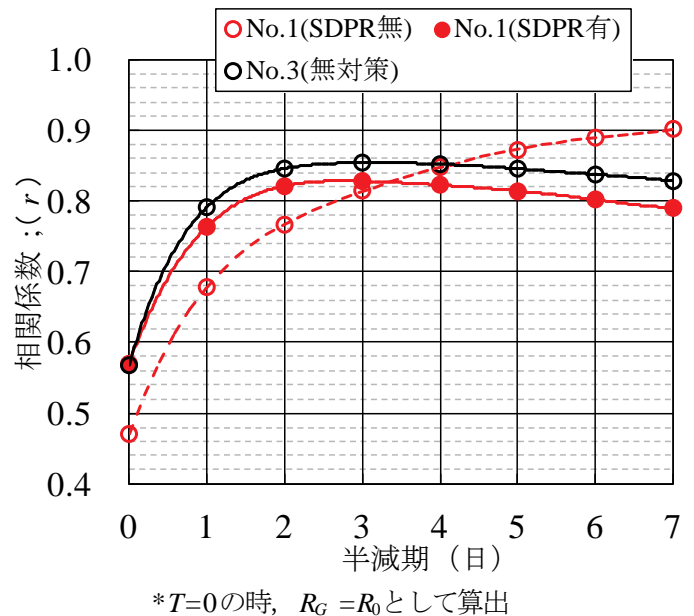

図-15 半減期ごとの相関係数（その 2)

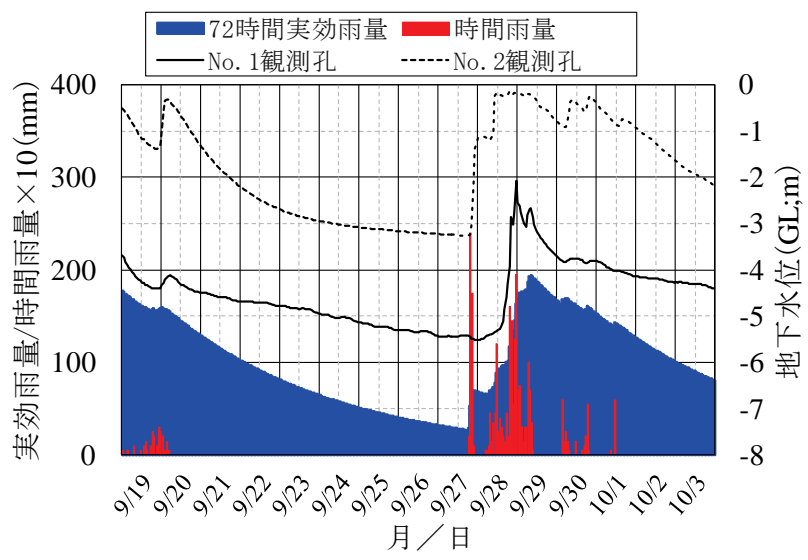

(2) SDPR 有 $(9 / 19 \sim 10 / 3)$

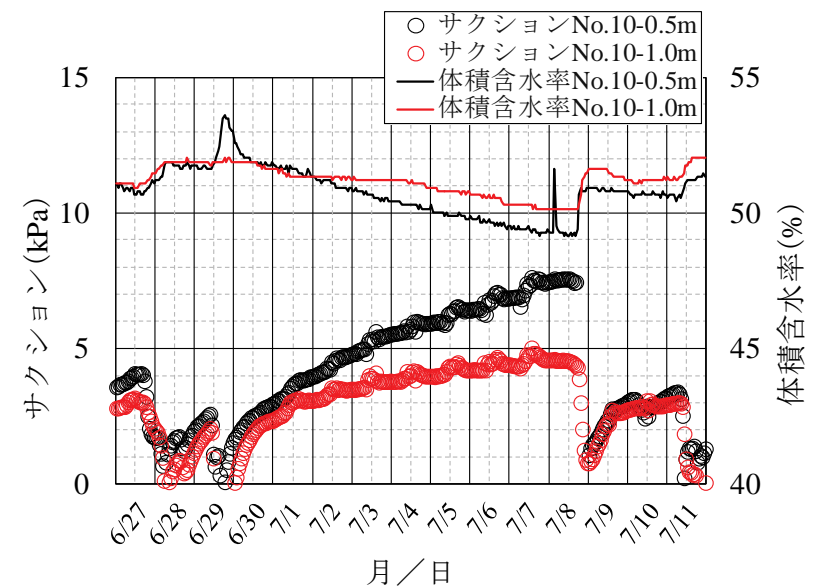

(1) SDPR 無(6/27 7/11)

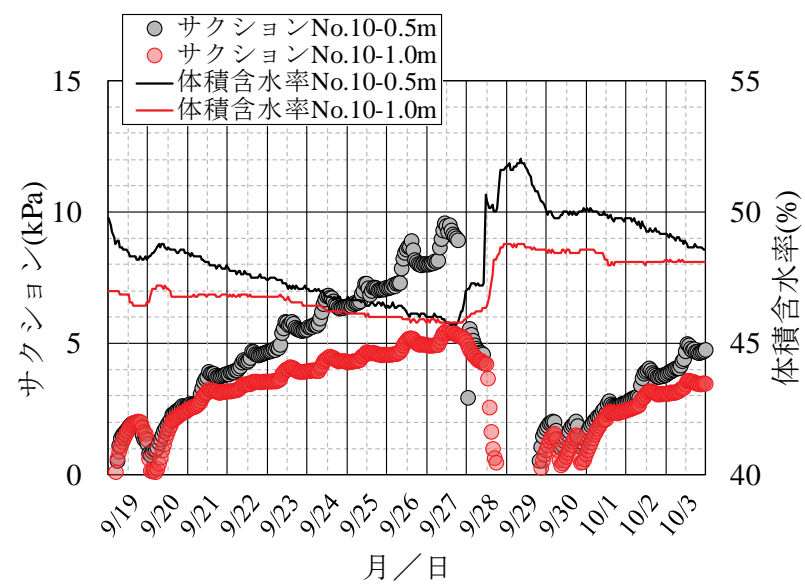

(2) SDPR 有(9/19 10/3)

図-17 サクションと体積含水率の計測結果（No.10地点） 


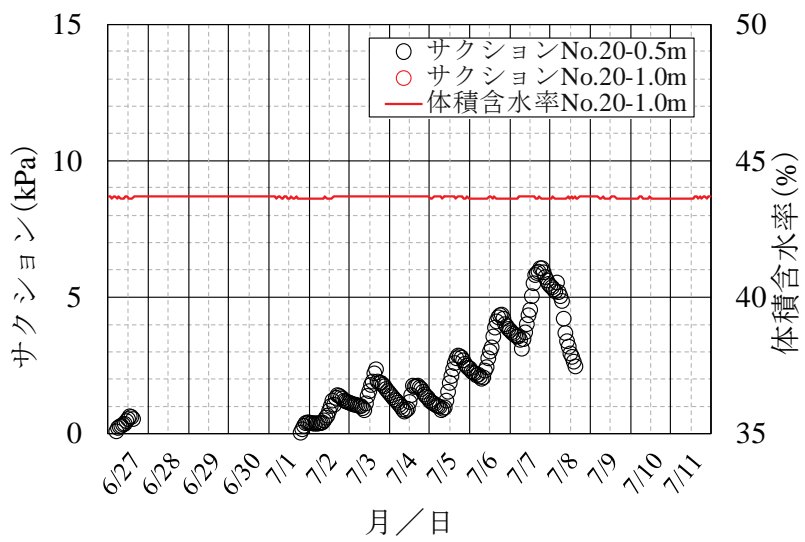

(1) $\operatorname{SDPR}$ 無(6/27 7/11)

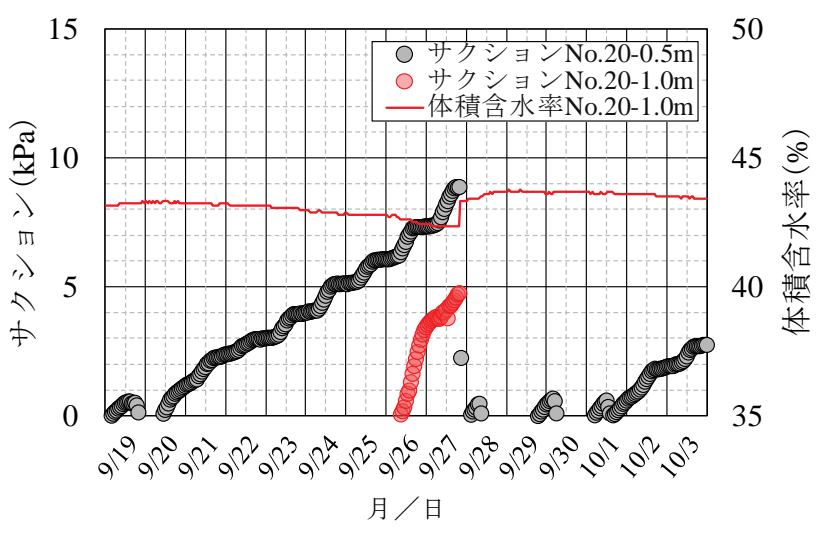

(2) SDPR 有 $(9 / 19 \sim 10 / 3)$

図-18 サクションと体積含水率の計測結果（No.20 地点）

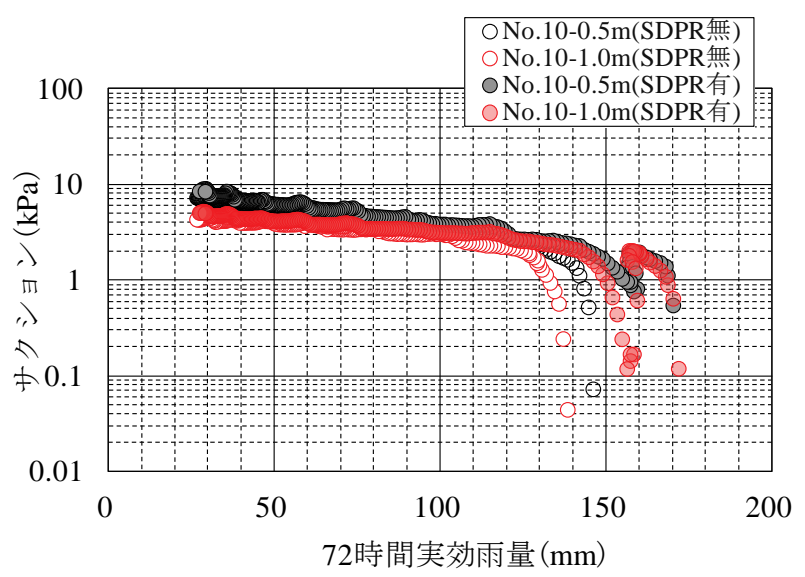

(1) のり肩部(No.10)

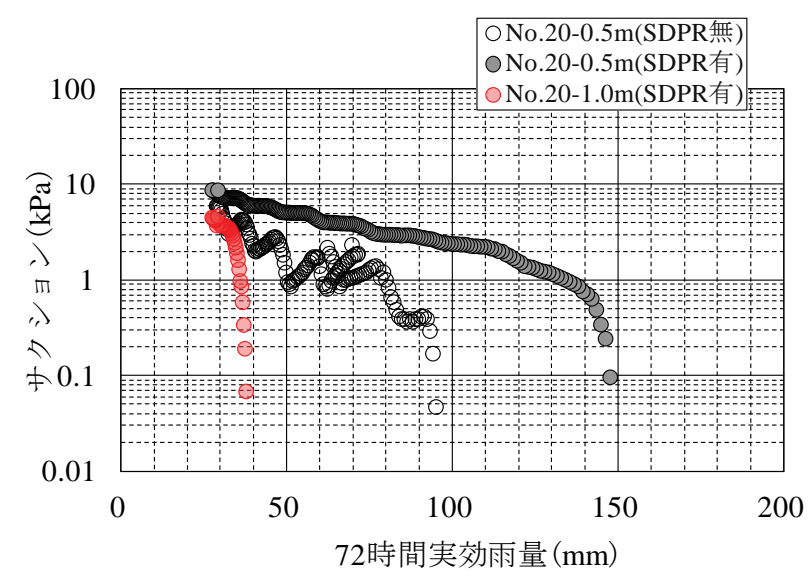

(2) のり尻部(No.20)

図-19 72 時間実効雨量とサクションとの関係

の 15 日間とし，この間の累積雨量は，258 mmであった。 No.2 観測孔（のり尻部）の地下水位（以下，「No.2 地 下水位」という）は，No.1 観測孔（のり肩部）の地下 水位（以下，「No.1 地下水位」という）より動態が激 しく，降雨の繰り返しにより定常的に高くなる傾向を示 した．また，No.1 地下水位および No.2 地下水位は，降 雨後時間の経過とともに，それぞれ GL-5.0m および GL$3.0 \mathrm{~m}$ 付近まで低下寸る傾向を示した.

地下水位の低下と 72 時間実効雨量 $\left(R_{G 72}\right)$ の減少に着目 した場合，SDPR 無では，72 時間実効雨量が 100mm 程 度（7/1: $\left.R_{G 72}=113 \mathrm{~mm}, 7 / 9: R_{G 72}=73 \mathrm{~mm}\right)$ に減少した時 に, No.2 地下水位は GL-1.0m 以下となった. 一方, SDPR 有では， 72 時間実効雨量が 150mm 程度（9/19： $\left.R_{G 72}=165 \mathrm{~mm}, 9 / 20: R_{G 72}=137 \mathrm{~mm}, 10 / 2: R_{G 72}=123 \mathrm{~mm}\right)$ に減少した時に, No.2 地下水位は GL-1.0m以下となった. また，No.1 地下水位が GL-4.0 m 以下となる時の 72 時 間実効雨量についても，SDPR 無では $100 \mathrm{~mm}$ 程度， SDPR 有では $150 \mathrm{~mm}$ 程度となり, No.2 地下水位と同様な 傾向が得られた。

このように，一定水位の低下に要する 72 時間実効雨 量に差異があることは, SDPR により地中に残存してい
表-7 モデル関数のパラメータ

\begin{tabular}{|c|c|c|c|c|}
\hline 地点 & $\begin{array}{c}\text { No.10 } \\
-0.5 \mathrm{~m}\end{array}$ & $\begin{array}{c}\text { No.10 } \\
-1.0 \mathrm{~m}\end{array}$ & $\begin{array}{c}\text { No.20 } \\
-0.5 \mathrm{~m}\end{array}$ & $\begin{array}{c}\text { No.20 } \\
-1.0 \mathrm{~m}\end{array}$ \\
\hline $\begin{array}{c}\text { 飽和時 72 時間 } \\
\text { 実効雨量 }\left(R_{s}: \mathrm{mm}\right)\end{array}$ & 170 & 160 & 150 & 40 \\
\hline $\begin{array}{c}\text { 最小 72 時間 } \\
\text { 実効雨量 }\left(R_{r}: \mathrm{mm}\right)\end{array}$ & 0 & 0 & 0 & 0 \\
\hline$\alpha$ & 0.03 & 0.03 & 0.055 & 0.02 \\
\hline$n$ & 3.0 & 6.0 & 2.0 & 2.0 \\
\hline$m$ & \multicolumn{4}{|c|}{$1-1 / n$} \\
\hline
\end{tabular}

る雨量が早く排出できていることを裏付けるものであり， SDPR により一定水位の低下に対して降雨後からの経過 時間が減少していることが示された。

\section{(5) サクションと体積含水率}

図-17 および図-18 は，サクションと体積含水率の計 測結果をとりまとめたものである。ただし，のり尻部の 深度 $0.5 \mathrm{~m}$ に設置した土壌水分計で計測した体積含水率 No.20-0.5m は，データの異常および久損が確認されたた め記載していない（図-18参照）。

図-17（凡例の番号等は表-6 中の番号等に対応）に示 すのり肩部（No.10 地点）の SDPR 無では，体積含水率 


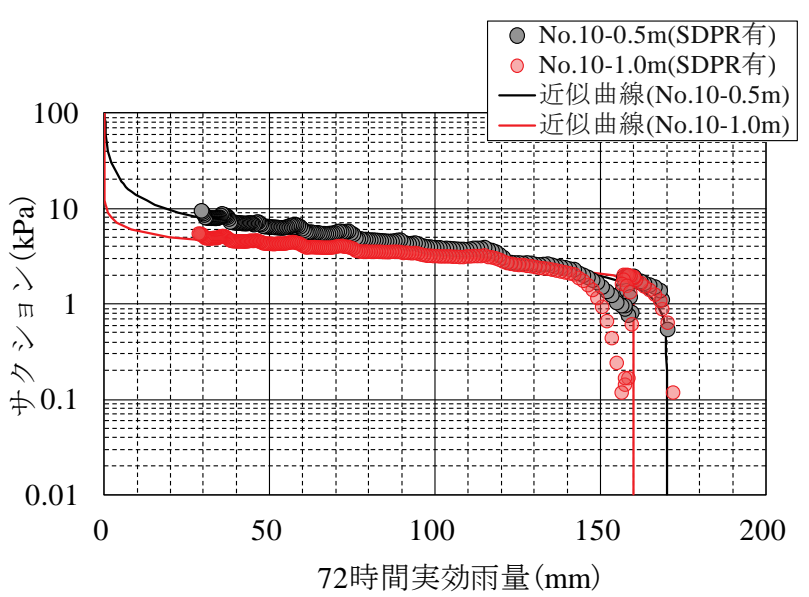

(1) のり肩部(No.10)

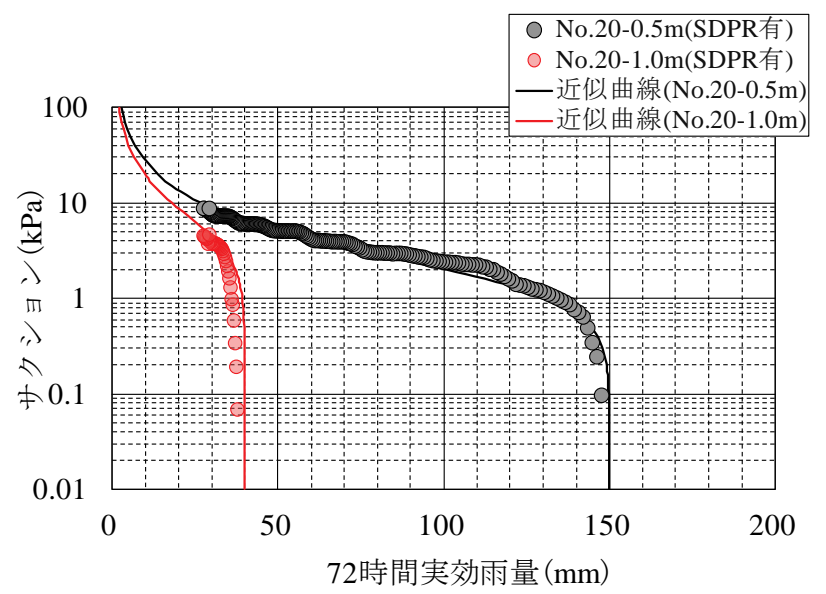

(2) のり尻部(No.20)

図-20 72 時間実効雨量とサクションとの関係（近似曲線）

はのり面表層に近い No.10-0.5m で 53.5\% 49.2\%の範囲で 変動し，51.9\%～50.2\%の範囲で変動した No.10-1.0m より も土壌水分の排水・吸水の動態が大きいことがわかる.

また，降雨後に体積含水率は徐々に低下し，それにあ わせて No.10-0.5m のサクションは 7.6kPa まで上昇してい る. サクションの上昇は，のり面表層に近い No.10-0.5m の方が顕著となっている. しかし，7月 8 日の降雨にみ られるように，サクションは急激に低下している.

一方，SDPR 有でも，SDPR 無と同様，体積含水率は のり面表層に近く 51.7\% 45.8\%の範囲で変動している No.10-0.5m の方が変動範囲は大きく， No.10-1.0m は 48.7\% 〜 45.8\%の範囲であった．また，降雨後に体積含水率は 徐々に低下するのに伴い，のり面表層に近い No.10-0.5m のサションは 9.6kPa まで上昇し, SDPR 無よりサクショ ンの上昇は大きくなる傾向を示した. しかし，9月 28 日の降雨にみられるように, SDPR 無の場合と同様, サ クションは急激に低下している.

次に図-18（凡例の番号等は表-6 中の番号等に対応） に示すのり尻部（No.20 地点）の SDPR 無では, 降雨後 にのり面表層に近い No.20-0.5mのサクションが 6.1kPa ま で上昇している．しかしながら，No.20-1.0m の体積含水 率は降雨後も 43.7\%のほぼ一定で推移しており，No.20$1.0 \mathrm{~m}$ ではサクションの回復は確認されていない.

一方，SDPR 有では，のり面表層に近い No.20-0.5m の サクションが $8.9 \mathrm{kPa}$ まで上昇している. また，No.20$1.0 \mathrm{~m}$ の体積含水率が $42.3 \%$ ま゙低下するのに伴い, サク ションは 4.7kPaまで上昇していることが確認された. こ のように SDPR 有では，降雨の影響で特に地下水位の変 動が著しいのり尻部においても体積含水率の低下に伴い サクションが回復する効果が確認でき, サクションの回 復力が高いことが示された.

また，図-17 および図-18 と図-16 を対比したときに， 体積含水率と地下水位の動態は 72 時間実効雨量の推移

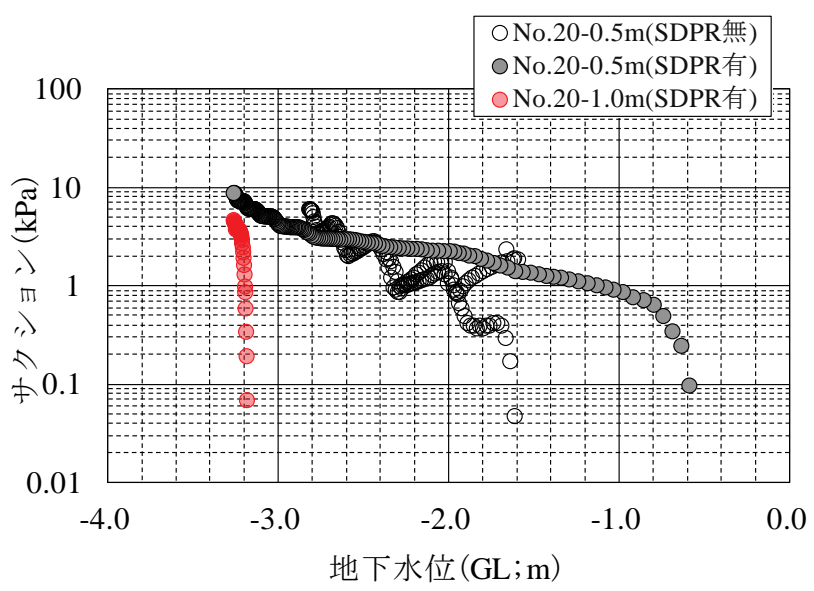

図-21 地下水位とサクションとの関係（のり尻部）

との相関が高いことがうかがえる.

\section{(6) 72 時間実効雨量とサクション}

図-17 および図-18 に示したように，サクションは降 雨の発生とともに急激に低下し消失している。ここでは, 消失したサクションが降雨後に回復する動態を捉え, そ の後のサクションの上昇に着目して検討を行った. まず, 消失していたサクションが回復し，その後の降雨により 再度サクションが減少するまでの排水過程イベントを抽 出した。

図-19 は，のり肩部（No.10 地点）とのり尻部（No.20 地点）のそれぞれの 72 時間実効雨量 $\left(R_{G 72}\right)$ とサクション との関係をプロットしたものである. SDPR 無について は，6月 29 日から年 7 月 8 日までを対象とし，SDPR 有 については，9月19日から9月 27 日までを対象とした。 のり肩部の SDPR 無では, No.10-0.5m および No.10$1.0 \mathrm{~m}$ において，サクションはそれぞれ $R_{G 72}=146 \mathrm{~mm}$ およ び $R_{G 72}=138 \mathrm{~mm}$ で回復した. その後サクションは, 72 時間実効雨量の減少に伴い上昇し， $R_{G 72}=30 \mathrm{~mm}$ の時に 
No.10-0.5m で 7.6kPa， No.10-1.0m で 5.0kPaに達した。

また，SDPR 有では，No.10-0.5m および No.10-1.0m に おいて，サクションはそれぞれ $R_{G 72}=170 \mathrm{~mm}$ および $R_{G 72}$ $=172 \mathrm{~mm}$ で回復した. その後サクションは, SDPR 無と 同様， 72 時間実効雨量の減少に伴い上昇し， $R_{G 72}=$ 29mm の時に No.10-0.5m で 9.6kPa, No.10-1.0m で5.5kPaに 達した。

一方，のり尻部の SDPR 無では，サクションは No.20$0.5 \mathrm{~m}$ において $R_{G 72}=95 \mathrm{~mm}$ で回復し， $R_{G 72}=29 \mathrm{~mm}$ の時に 6.1kPa に達したが， No.20-1.0m ではサクションの回復は 確認されなかつた.

また，SDPR 有では，No.20-0.5m および No.20-1.0m に おいて，サクションはそれぞれ $R_{G 72}=147 \mathrm{~mm}$ および $R_{G 72}$ $=38 \mathrm{~mm}$ で回復した. サクションは, その後のり肩部と 同様，72 時間実効雨量の減少に伴い上昇し, $R_{G 72}=$ 29mm の時に No.20-0.5m で 8.9kPa，No.20-1.0m で 4.7kPa に 達した。

このように，72 時間実効雨量が減少するとサクショ ンが回復し，さらにサクションは上昇する結果が得られ た. サクションは, SDPR の有・無にかかわらずのり面 表層に近い方が大きくなる傾向を示し，またのり尻部よ りのり肩部の方が早期に回復しやすい傾向を示した.さ らに SDPR 有のサクションは, SDPR 無と比較して 72 時 間実効雨量が大きい時点で回復しており，降雨の影響で 地下水位の変動が著しいのり尻部においては, SDPR 有 のみにサクションの回復が確認され，体積含水率の低下 の場合と同様，サクションの回復力が高いことが示され た.

\section{（7）実効雨量を用いたサクションの推定}

のり面の安定性を検討するには，先行雨量の影響や降 雨特性とあわせて, 降雨による地盤内部の土壌水分やサ クションの動態を明らかにし，それを正確に表現できる 手法を確立する必要がある.

ここでは，SDPR の排水効果によるサクションの回復 および上昇過程を 72 時間実効雨量により予測すること を試みた. 図-16〜図-18に示したように，72 時間実効雨 量の推移は地下水位や体積含水率の動態と同様な傾向を 示すことから，先行雨量の影響を考慮した 72 時間実効 雨量によるサクションの推定は, 降雨後のサクションの 回復を簡便に評価する手法として期待できる.

次式 (5) に示すように，不飽和・飽和浸透解析の水分 特性曲線を求めるモデル関数として一般的に用いられて いる van Genuchten 式 ${ }^{24}$ のモデル関数を参考に，表-7に示 すパラメータを用いて, 図-20 に示す近似曲線へのフィ ッテイングを試みた。

$$
\frac{R_{G 72}-R_{r}}{R_{s}-R_{r}}=\frac{1}{\left\{1+(10 \cdot \alpha \cdot S)^{n}\right\}^{m}}
$$

ここに, $R_{G 72}$ ： 72 時間実効雨量 $(\mathrm{mm}), R_{s}$ ： 飽和時 72 時間実効雨量 $(\mathrm{mm}), R_{r}$ ：最小 72 時間実効雨量 $(\mathrm{mm})$, $S$ : サクション $(\mathrm{kPa}), \alpha \cdot m \cdot n$ : 定数である.

飽和時 72 時間実効雨量 $\left(R_{s}\right)$ は，それぞれの計測地 点・深度においてサクションが回復したときの 72 時間 実効雨量とし，最小 72 時間実効雨量 $\left(R_{r}\right)$ は，72 時間実 効雨量とサクションに関するデータが限定的であるので, 便宜的に $R_{\mathrm{r}}=0 \mathrm{~mm}$ とした.

図-20 に示すように，近似曲線は土壌水分の排水過程 におけるサクションの発生ならびに 72 時間実効雨量の 減少に伴うサクションの上昇が適切に表現可能となって いる。また，それぞれのサクションの実測值と近似曲線 によるサクションの推定值の相関係数は $r=0.95 \sim 0.99$ が 得られ，両者にはかなり強い相関があり，降雨後のサク ションの動態を推定できることが示された.

\section{（8）地下水位とサクション}

図-21 は，降雨イベント後の排水過程におけるサクシ ヨンの動態のうち, SDPR により排水効果が顕著であつ たのり尻部における地下水位とサクションとの関係をプ ロットしたものである.ここで，のり尻部の地下水位は， No.2 観測孔により観測された地下水位であり，SDPR 無 については，前述した期間のうち7月 1 日から 7 月 7 日 までを対象とし，SDPR 有については，9月 20 日から9 月 27 日までを対象とした。

SDPR 無では，サクションは No.20-0.5m において地下 水位が GL-1.6m で回復したが，No.20-1.0mにおいては， 図-16 に示すように地下水位が GL-2.9m まで低下しても サクションの回復は確認されなかった.

一方, SDPR 有では, No.20-0.5m および No.20-1.0m の サクションは，それぞれ地下水位が GL-0.6m および GL-3.2m で回復した. サクションは，その後の地下水位 の低下により上昇しているが，地下水位が GL-3.0m以下 となると急激に上昇することが確認できた.

このように，SDPR 有は特に地下水位の変動が著しい のり尻部において，サクションの動態で SDPR 無とあき らかな差異を示した。

\section{7. まとめ}

本稿では，排水機能を有するスパイラル羽根付き鋼管 の原位置試験を通じて，のり面の安定検討に必要な鋼管 と地盤との付着性能や，地下水位およびサクションの動 
態からみた排水性能について，下記の知見が得られた。

(1) 代表 $N$ 值= 10 程度以下の地盤であれば，エアモー タ・チェーン方式のボーリングマシンを用いた据り込 み方式の施工により，鋼管の圧入が可能である.

(2) 鋼管は，地盤との全面接着による一体化が期待でき, 地盤の代表 $N$ 值と相関がよい付着性能を示し，極限 周面摩擦抵抗 $(\tau)$ は地盤の代表 $N$ 值により推定が可能 である。

(3) 先行雨量の影響を考慮した実効雨量の推移と地下水 位の動態はよい相関を示し，SDPR により地下水位の 上昇を抑制できるとともに，地盤に浸み込み残存して いる雨量の指標となる実効雨量の半減期を縮減できる

(4) コルモゴノフースミルノフ検定および回帰分析によ り，一定の水位上昇に対する限界実効雨量が増大寸る ことを明らかにでき，SDPR による而降雨性の向上を 定量的に評価できた.

(5) サクションは降雨後の実効雨量が減少するとともに 回復し，一定の実効雨量に達すると急激に増加する. また，SDPRによりその経過過程が早くなる。

(6) 降雨に伴い地下水位が上昇し地盤強度の低下が著し いのり尻付近においては，SDPR によりサクションの 回復力が高い.

(7) サクションは実効雨量の推移と強い相関関係にあり, 水分特性曲線のモデル構成式により推定可能となり, 降雨後ののり面安定検討に活用できる可能性がある.

\section{8. おわりに}

本稿では，SDPR の実施工を通じた原位置試験，地下 水位観測およびサクション計測にもとづく検討により， 鋼管と地盤との付着性能，地下水位の上昇抑制やサクシ ヨンの動態について，SDPR による付加的効果を実験的 に検証することができた.

今後は，飽和一不飽和浸透流解析等を用いた鋼管の最 適な配置密度や配置長さなどの検討を行い，SDPR によ る予防保全対策の合理的設計システムの構築を目指して いきたい.

\section{参考文献}

1) 大窪克己，浜崎智洋，北村佳則，稲垣太浩，濱野雅 裕，佐伯宗大，龍岡文夫：高速道路盛土の大規模地 震時の耐震性検討(その 2) 〜変位量による耐震性能評 価法の検討〜，第 39 回地盤工学研究発表会講演集， No. 882, pp. 1761-1762, 2004.

2) 藤岡一頼, 安田進, 白鳥翔太郎：道路盛土材料の動 的強度特性, 土木学会論文集 A1 (構造・地震工学), Vol. 65, No. 1, pp. 875-880, 2009.

3) 横田聖哉, 石田誠幸, 高木宗男 : 駿河湾の地震にお
ける高速道路盛土の被災調査報告，地盤工学会第 45 回地盤工学研究発表会講演集, No. 747, pp. 1493-1494, 2010.

4) 安部哲生, 横田聖哉, 日下寛彦, 金田和男：東北地 方太平洋沖地震における高速道路盛土の地震被害に ついて一常磐自動車道那珂地区一, 地盤工学会第 47 回地盤工学研究発表会講演集, No. 482, pp. 959-960, 2012.

5) 高速道路資産の長期保全及び更新のあり方に関する 技術検討委員会 : 報告書, 2014 .

6) 西日本高速道路(株) : http://corp.w-nexco.co.jp/corporate /release/hq/h28/0330c/，2016.3.

7) 松坂敏博，森山陽一，小笹浩司，太田秀樹，藤野陽 三，宮川豊章，西村和夫：高速道路の構造物におけ る大規模更新および大規模修繥の導入と課題，土木 学会論文集 F4 (建設マネジメント), Vol. 73, No. 1, pp. 1-18, 2017.

8) 下間英，前田賢悟，本多剛，ORENSE P. Roland，東 畑郁生：降雨による斜面崩壊の予測に関する模型実 験, 第 37 回地盤工学研究発表会講演集, No. 1084, pp 2159-2160, 2002.

9) 地盤工学会：地震と豪雨・洪水による地盤災害を防 ぐために一地盤工学からの提言一，2009

10) 鵜飼恵三, 祭飛, 若井明彦, 坂上最一：集水ボーリ ング工の効果に関する定量的評価手法の提案，地す ベり, Vol. 35, No. 3, pp. 1-7, 1998.

11）秋田剛，常田賢一：既設道路盛土の安定性向上のた めの排水パイプの適用性の検証，近畿地方整備局研 究発表会, 防災・安全部門, No. 22, 2012.

12) 渡邊論, 西田幹嗣, 浅野嘉文, 杉山友康, 西垣誠: 排水パイプが打設された盛土の弾塑性 FEM を用いた 安定性評価に関する一考察, 第 48 回地盤工学研究発 表会講演集，No. 571, pp. 1141-1142, 2013.

13) 藤岡一頼，大窪克己：高速道路土工部における降雨 災害分析，第 27 回日本道路会議，2007.

14) 土木学会 : 回転圧入鋼管杭(NS エコスパイラル)の設 計施工法に関する技術評価報告書, 技術推進ライブ ラリーNo. 7, 2015.

15）荒井昭浩，森川脩之，竹山智英，日下部治，佐伯英 一郎，澤石正道：高地下水面を有する盛土構造物の 崩壊機構の把握と鋼管杭を応用した耐震性改善の提 案，第 46 回地盤工学研究発表会講演集，No. 551, pp. 1107-1108, 2011.

16）澤石正道，和田昌敏，菅野浩樹，上村健太，高橋章 浩：盛土の斜面安定対策工としての小径羽根付き鋼 管の補強効果に関する実大実験, 地盤工学ジャーナ ル, Vol. 11, No. 3, pp. 215-228, 2016.

17) 中村大樹，笠間清伸，浜崎智洋，古川全太郎：穴女 きパイプを挿入した盛土の浸透流解析，第 7 回土砂 災害に関するシンポジウム論文集，pp. 217-222, 2014.

18）古川全太郎，笠間清伸，浜崎智洋，中村大樹：盛土 に打設した排水性補強材の降雨・地震時の安全率改 善効果，第 8 回土砂災害に関するシンポジウム論文 集, pp. 235-240, 2016.

19) 西日本高速道路(株)：切土補強土工法設計 - 施工要領, pp. 33, 2007.

20) 地盤工学会 : 地盤調査の方法と解説, pp. 310, 2013.

21) 気象庁: 確率降水量の推定方法, http://www.data.jma. go.jp/cpdinfo/riskmap/cal_qt.html, 2017.3. 
22) 地盤工学会 : 豪雨時における斜面崩壊のメカニズム および危険度予測, pp. 113, 2006.

23) Ang, A. H.-S. and Tang, W. H. : Probability Concepts in Engineering, John Wiley \& Sons, 2007. (伊藤學，亀田弘 行, 能島暢呂, 阿部雅人 訳 : 土木・建築のための確 率・統計の基礎，pp. 361-364, 丸善，2007.)
24) van Genuchten, M. Th. : A closed-form equation for predicting the hydraulic conductivity of unsaturated soils, Soil Science Society of America Journal, Vol. 44, pp. 892-898, 1980.

(2017. 4. 11 受付)

\section{FIELD TEST FOR EMBANKMENT REINFORCEMENT USING SPIRAL BLADED DRAIN PIPES}

\section{Tomohiro HAMASAKI, Kiyonobu KASAMA, Satoshi TAYAMA, Yoshito MAEDA, Kenji MATSUKATA and Ryohei AKIYOSHI}

The purpose of this study is to develop a new earth reinforcement technology using spiral bladed drain pipes called "SDPR method", which has both functions of an earth reinforcement to increase a pulling resistance with the spiral shape blades and a drainage pipe to lower a ground water level in the embankment.

This paper summarizes the field test results of pull-out test and the observation of water retention characteristics for the expressway embankment with SDPRs. The pull-out test confirms that the friction resistance between the single SDPR and ground can be provided for the stability design of the embankment with SDPRs. The field observation of suction and volumetric water content in the embankment with/without SDPRs confirms the effectiveness of the SDPR method about the drainage performance, lowering of the ground water level and the quick restoration of the suction. 